AperTO - Archivio Istituzionale Open Access dell'Università di Torino

\title{
Richter Syndrome in Chronic Lymphocytic Leukemia
}

\section{This is a pre print version of the following article:}

Original Citation:

\section{Availability:}

This version is available http://hdl.handle.net/2318/1695846

since 2019-03-30T14:22:21Z

Published version:

DOI:10.1007/s11899-016-0300-y

Terms of use:

Open Access

Anyone can freely access the full text of works made available as "Open Access". Works made available under a Creative Commons license can be used according to the terms and conditions of said license. Use of all other works requires consent of the right holder (author or publisher) if not exempted from copyright protection by the applicable law. 
Richter syndrome in chronic lymphocytic leukemia

Candida Vitale and Alessandra Ferrajoli

Department of Leukemia, The University of Texas MD Anderson Cancer Center, Houston, TX

Correspondence: Alessandra Ferrajoli, MD, Department of Leukemia, Unit 428, The University of Texas MD Anderson Cancer Center, 1515 Holcombe Boulevard, Houston TX, 77030; E-mail: aferrajo@mdanderson.org; Tel. 1(713)792-2063; Fax.1(713)792-9616. 


\section{Abstract}

The term Richter Syndrome (RS) indicates the transformation of chronic lymphocytic leukemia (CLL) into an aggressive lymphoma. RS is a rare complication with an aggressive clinical course, bearing an unfavorable prognosis.

In the majority of cases CLL transforms into RS as diffuse large B cell lymphoma (DLBCL), and a clonal relation between the two processes can be found. However, clonally unrelated RS can occur and transformations to other histologies beside DLBCL have been described.

Recent data have shed some light on genetic characteristics that can influence and drive the transformation from CLL to RS. This molecular information has not been translated yet into significant treatment advances, and currently the therapy regimens for RS continue to rely on intensive chemotherapy combinations followed by stem cell transplant in suitable candidates.

Based on the rapid pace of discoveries in the field of hematological malignancies and on the recent revolution in the therapeutic landscape for CLL and B cell lymphomas, new therapeutic options for RS might be available in the upcoming years. 


\section{Introduction}

In chronic lymphocytic leukemia (CLL), Richter syndrome (RS) is a rare complication. However, it has relevant clinical implications due to its aggressive clinical course and poor prognosis.

The specific pathologic features of RS were initially described in 1928 by Maurice Richter [1], and approximately 40 years later the term RS was first used referring to a series of patients with CLL who developed diffuse large B cell lymphoma (DLBCL) [2]. Currently, according to the 2008 World Health Classification of lymphoid neoplasms, RS is defined as the transformation of CLL into an aggressive lymphoma [3]. The vast majority of RS cases are "classical" transformation to DLBCL and, based on the immunoistochemical Has-Choi algorithm [4], they can mainly be categorized as the more aggressive activated B-cell subtype $(A B C)[5,6]$. However, a much less common evolution to Hodgkin lymphoma (Hodgkin variant of RS, HVRS) has been described [7].

A reliable appraisal of the incidence of RS is difficult to obtain due to the heterogeneity of the population studied in the published retrospective analysis, and to the lack of a uniform diagnostic approach among centers. It is conceivable that the proportion of patients developing RS is generally underestimated because many patients with aggressive clinical features will not undergo biopsy. Large retrospective studies including more than 500 patients with CLL describe a prevalence of RS ranging from 2 to $9 \%$ [8-11], with an approximate incidence rate of $0.5 \%$ per year [11]. In these same studies, the reported median time to development of RS is approximately 2 years [10,11], not supporting the common notion that RS tend to occur late in the natural history of CLL. A longer interval between the diagnosis of CLL and the transformation to RS (median 4.3 years) has been reported in a retrospective analysis of patients with HVRS [12].

\section{Molecular features of RS}


One of the key molecular characteristic of RS is that this disease includes two distinct categories based on its cell of origin: in $80-90 \%$ of cases $\mathrm{RS}$ is related to the original CLL clone (clonally related RS), whereas in a small percentage of RS cases the aggressive malignant clone is independent from the original CLL clone (clonally unrelated RS) [6]. While the absence of clonal relationship is easily recognized at the time of immunophenotypic studies in patients with different immunoglobulin light chain restriction between the CLL and DLBCL tissue samples, in cases where the light chain restriction is the same additional molecular approaches should be performed to better characterize the process. The most widely used method consists in the study of the immunoglobulin heavy chain variable region (IGHV) rearrangement through polymerase chain reaction (PCR) and sequencing [13]. An identical nucleotide sequence in the IGHV rearrangement between CLL and RS samples supports the clonal relationship. However, it needs to be highlighted that this analysis is not feasible in all laboratories. Moreover, the study cannot be performed in certain patients because of the unavailability of baseline IGHV sequencing of the CLL B cells, or because of the presence of a mixed population of CLL and aggressive lymphoma in the RS histological sample.

The distinction between clonally related and unrelated RS has clinical implications. In fact, the former, which can be considered a true transformation, has a poor outcome, whereas the latter has a significant better prognosis and behaves more like de novo DLBCL [5]. In HVRS, the malignant cells morphologically and immunophenotypically resemble classical Hodgkin lymphoma Reed-Sternberg cells in the majority of cases. The clonal relation of the Reed-Sternberg cell with the original CLL clone has been shown only in some cases, but no definitive molecular data on the pathogenesis are available, possibly due to the rarity of this variant [12].

Recently published molecular data contributed to the understanding of the pathways and mechanisms involved in RS transformation. Rossi and colleagues analyzed samples from 
86 cases of classic RS and found TP53 disruption in 47\% and c-MYC abnormalities in $26 \%$, whereas other genetic alterations that are common in de novo DLBCL were virtually absent [5].

The genetic dissimilarity of RS as compared to DLBCL had already been postulated by Fabbri et al., who compared the frequency of the most prevalent genetic lesions in 27 RS cases and in 71 newly diagnosed and previously untreated DLBCL cases $(A B C n=40$; Germinal center B-cell, GCB n=31). In their work these authors showed that the genetic lesions found in RS significantly differ from that of both de novo ABC DLBCL and GCB DLBCL [14]. Chigrinova and colleagues performed a genome-wide DNA profiling analysis in CLL ( $n=315$ ), CLL samples of patients that subsequently developed RS ( $n=28)$, de novo DLBCL ( $n=127)$, and RS ( $n=59)$, and compared the specific copy number changes in different groups, concluding that the genomic complexity of RS can be considered intermediate between CLL and DLBCL [15]. Interestingly, significant differences between RS and de novo DLBCL were also detected in terms of methylation profile, underscoring that these two entities with similar histopathology are in fact distinct, not only genetically, but also epigenetically [16].

Chigrinova et al. also described two different pathways of molecular transformation from CLL to RS, which are mutually exclusive. In approximately one half of the cases, TP53 and CDKN2A aberrations were detected and considered responsible for the RS transformation, whereas in one third of patients the presence of trisomy 12, associated with NOTCH1 mutations, was considered to be implicated in the histologic shift [15].

The sequence of molecular progression from indolent to aggressive disease was explored by Fabbri and colleagues, who analyzed samples from 9 CLL-RS pairs and from an extended panel of 43 RS cases by combining whole-exome sequencing and copy-number analysis. The authors showed that usually RS derives from the acquisition by the original CLL clone, in a linear fashion, of approximately 20 new genetic lesions, which are 
nevertheless very heterogeneous [14]. It has also been suggested that in clonally related RS - as it happens in progressive CLL- small subclones mutated for TP53 or with other detrimental genetic aberrations can be already present in the original CLL clone and later expand and become the predominant clone due to the selective pressure of treatment [17]. The genetic instability driven by the loss of tumor suppressors (TP53 and CDKN2A) and by the lack of control of the cell cycle (c-MYC aberrations) may explain the accumulation of genetic lesions and the transformation from CLL to RS.

It has also been proposed that a contributor to the clonal evolution from CLL to RS - in particular to HVRS - may be an infection from Epstein-Barr virus (EBV) in patients characterized by an extremely dysregulated immune system $[7,18]$.

\section{Clinical risk factors}

The risk of transformation to RS has been associated with few clinical risk factors, such as the volume of lymph nodes and advanced Rai or Binet stage at diagnosis $[11,13]$. The relationship between treatment and development of RS is controversial. A role of CLLdirected treatment and in particular the use of specific drugs, in the development of RS has been hypothesized. However, patients with CLL receive different type of therapy regimens in a sequential manner, and therefore the specific contribution of a single class of drugs is difficult to determine. In the recent cohort study conducted at Mayo Clinic, RS was diagnosed in $37 / 1,641$ patients, and in approximately half of the patients the diagnosis occurred prior to any specific CLL treatment. Among the treated patients, the exposure to a combination of purine analogues and alkylating agents was associated with a higher risk of RS as compared to both agents administered alone (OR 3.26) [11]. This is in contrast with the results of two other studies, which showed no difference in RS incidence in patients treated with purine analogues, alkylating agents, or a combination of the two $[19,20]$. 
With the current availability of novel non-chemoterapic drugs, such as Bruton tyrosine kinase (BTK) inhibitors, phosphatidylinositol-3-kinases (PI3K) inhibitor, and BCL-2 antagonists for the treatment of CLL, a new clinical landscape emerges. Two independent studies showed an incidence of RS of $5-6 \%$ in patients undergoing ibrutinib therapy, and the majority of these patients transformed within the first 12 months of therapy $[21,22]$. More data are needed to exclude that the transformation to RS was driven by the treatment itself (i.e. contributing to the clonal evolution), even if the short time between the treatment initiation and the development of RS could suggests the presence of an unrecognized RS at the initiation of ibrutinib. Furthermore, future studies evaluating the development of RS in patients treated with other targeted treatments will be helpful to answer this open question.

\section{Biological and molecular risk factors}

Substantial efforts have been directed to the identification of biological characteristics of the CLL cells that could predict the transformation to RS. Several characteristics of the CLL cells with a recognized prognostic impact have been shown to also influence the transformation to an aggressive disease. Patients carrying unmutated IGHV or high-risk genetic abnormalities (i.e. del11q and del17p) detected by fluorescence in situ hybridization, as well as patients with high expression of CD38, ZAP70 and CD49d in CLL cells have a higher risk of developing RS $[11,13]$.

The usage of stereotyped B cell receptor (BCR) characterizes approximately one third of CLL cases, and it was found to be associated with a higher risk of transformation to RS (14\% vs 4\% 5-year risk) [10]. These data were later confirmed in an independent cohort of patients (5\% vs 1\%) [11]. Moreover, the association between the preferential use of IGHV 4-39 and the development of RS was initially described, but later not confirmed, possibly 
due to the association of this molecular characteristic with other unfavourable genetic features such as NOTCH1 mutations and trisomy $12[10,11,23]$.

One of the most important molecular features recently reported is NOTCH1 mutation which characterizes patients with CLL at increased risk of transformation to RS $[24,25]$. Short telomeres, an indicator of genetic instability, have been shown to serve not only as a negative prognostic biomarker in CLL, but also as a predictor of RS transformation [26]. However, not all negative prognosticators in CLL maintain a role in the development of RS. For example, SF3B1 mutations have no impact on the risk of transformation to an aggressive disease as shown in a cohort of 605 patients with CLL [25]. This is an important finding, highlighting how the biologic and molecular pathways leading to RS differ, at least in part, from the ones involved in CLL aggressiveness.

In the quest for other possible risk factors for the development of RS, single nucleotide polymorphisms (SNPs) have also been studied. In a group of 248 patients with CLL, a SNP in the CD38 gene (rs6449182) was shown to have a higher frequency in patients carrying other markers of unfavorable prognosis and in patients who developed RS [27]. In another cohort of 331 patients with CLL, a significant association with the risk of transformation to RS was found for a SNP on the LRP4 gene (rs2306029) that codes for a protein with a role in the $\mathrm{Wnt} / \beta$-catenin signaling pathway, which is known to be deregulated in CLL [28].

Of note, the majority of the reported data derive from retrospective cohort analysis, and prospective studies are therefore needed to validate these observations.

\section{Diagnostic approach}

The suspicion for RS is generally clinical. The clinical presentation is similar for patients with classical RS and HVRS. Patients typically present with systemic symptoms, such as persistent fever without a detectable infectious source or weight loss, high levels of lactate 
dehydrogenase (LDH), hypercalcemia, and rapidly progressive lymphoadenopathies. Since these signs and symptoms are not specific for RS, but they may also accompany a progression of CLL without transformation, a histological diagnosis is mandatory. RS does not usually equally involve all lymph nodes, therefore a PET scan is recommended not only to evaluate the proliferative activity of the disease, but also to better direct the histological sampling to the most suitable area.

The first study exploring the diagnostic performance of PET scan in detecting RS was published in 2006, and showed that using as a SUVmax cut-off of 5 the sensitivity and negative predictive value were high (91\% and $97 \%$, respectively) [29]. Similar percentages (sensitivity $88 \%$, negative predictive value $92-94 \%$ ) were confirmed in two later studies analyzing 95 and 17 patients with RS, respectively [30,31]. However, it has been recently shown in a cohort of 24 patients with RS that a SUVmax threshold of $>10$ may be more accurate in correctly classifying the patients [32]. PET scan does not discriminate between RS, non-hematological malignancies, infections, and CLL with high FDG avidity, and the low positive predictive value of this test (38-53\%) strongly advocates for a histological confirmation in all cases of SUVmax $\geq 5[30,31]$. A lymph node biopsy, directed to a site of highly FDG-avid disease, should be preferred because fine needle aspirates are usually not sufficient to obtain a definitive diagnosis and have been shown to be inadequate in more than half of the RS cases [30]. From an histopathological point of view, the differential diagnosis includes "accelerated CLL" (characterized by expanded proliferation centers without histologically proven DLBCL) [33], prolymphocytic transformation [34], composite lymphoma (concomitant finding of two different lymphoproliferative diseases at the same time in the same tissue) [35], as well as unrelated causes such as infections and other neoplastic diseases.

Interestingly, it has recently been shown that patients with CLL whose histology is showing different grades of aggressiveness, but have similar SUVmax, have comparable clinical 
outcomes. In this study, patients with CLL, high SUV and histological features of intermediate aggressiveness (increased large cells, large confluent proliferation centers, or high proliferation rate) showed a clinical behavior similar to that of patients with RS, and a survival intermediate between patients with indolent CLL and RS [30]. Although rare, extranodal localization of RS has been reported and may in some cases be detected by the PET scan. In particular, there are anecdotal cases of ocular, central nervous system (CNS), gastrointestinal system, skin, testis, lung, and kidney localization (reviewed in [36]). Beside tissue biopsies, a bone marrow biopsy and aspirate should also be performed in all patients to complete the staging.

Lastly, it should also be strongly emphasized that there is currently no clinical value of the PET scan for routine evaluation of CLL in the absence of a clinical suspicion of transformation [37].

\section{Prognosis}

As previously discussed, one of the main determinant of survival in patients with RS is the clonal relationship between the original CLL and the transformed disease. In clonally unrelated cases the median survival is comparable with de novo DLBCL and is significantly longer compared to patients with clonally related RS [5]. In clonally related RS, median survival varies between series, mostly between 8-24 months. In a series of 50 clonally related patients with RS an overall survival (OS) of 14.2 months (95\% Cl 7.7-20.6 months) was reported [5]. Another group reported a median survival of 8 months $(95 \% \mathrm{Cl}$ 6-10 months) in a cohort of 148 patients with biopsy or FNA-proven RS [9]. In a cohort of 37 patients studied at Mayo Clinic, the median OS after development of RS was 2.1 years [11], and Mauro et al. reported an OS probability at 40 months of $13 \%$ for patients with a histologically-confirmed RS [31]. The OS in a retrospective series of 86 cases of HVRS was 1.7 years from RS diagnosis [12]. 
Several models based on clinical and laboratory features have been developed to help determining the prognosis of patients with RS, considering that the assays to analyze the clonal relationship between CLL and RS are cumbersome and not available in all centers. A score which was able to predict the risk of death in patients with RS, taking into account performance status, LDH level, platelet count, and number of prior lines of therapy was developed at The University of Texas MD Anderson Cancer Center [9]. The validity of this score was later proven by an independent group on a different cohort of patients [11]. Another algorithm based on TP53 disruption, response to RS treatment, and performance status has been shown to predict RS prognosis, with survival durations ranging from less than one year for high risk patients to a 5-year survival of $70 \%$ for low risk patients [5]. Moreover, it has also been shown that a higher SUVmax at PET scan correlates with inferior survival in patients with RS, and that PET response - being an indicator of chemosensitivity - correlates with prognosis. In fact, in chemoresistant patients the median OS is significantly shorter compared to chemosensitive patients (15.3 months vs not reached at a median follow-up of 35.9 months) [30].

\section{Therapeutic approach}

Whereas it is overall accepted that clonally unrelated transformation to DLBCL should be managed and treated as a de novo DLBCL, more uncertainty exists for clonally related RS. Due to the low incidence of RS, all data on treatment response and tolerability derive from single-arm phase II studies or retrospective analysis, and there are no available evidences from randomized trials. The most relevant results from clinical trials exploring different therapeutic approaches in RS are shown in Table 1.

Historically, anthracycline-based regimens (most commonly cyclophosphamide, doxorubicin, vincristine, and prednisone, $\mathrm{CHOP}$ ) possibly in association with rituximab ( $\mathrm{R}$ $\mathrm{CHOP}$ ), derived from the standard treatment of $\mathrm{B}$ cell lymphomas, have been used to treat 
patients with RS [38,39]. However, a systematic evaluation of the efficacy of R-CHOP regimen in patients with $\mathrm{RS}$ was recently published and outlined its modest activity. Langerbeins and colleagues reported the results on 15 patients with RS and showed an overall response rate (ORR) of $67 \%$, a progression free survival (PFS) of 10 months and an OS of 21 months. Moreover, a high incidence of severe infections (28\%), hematologic toxicities (92\%), and a treatment related mortality of $5 \%$ were reported [40]. The addition of rituximab to chemotherapy is confirmed to improve the OS of patients with RS in a retrospective cohort of 81 patients (2-year OS $42 \%$ vs $19 \%, p=0.001$ ) [41]. A phase II study evaluating efficacy and tolerability of CHOP in combination with ofatumumab as induction and maintenance for patients with newly diagnosed RS is currently ongoing, but results have not been presented yet [42].

With the aim of improving the treatment efficacy, other anthracycline-based regimens have been evaluated in clinical trials. Twenty-nine patients were treated at The University of Texas MD Anderson Cancer Center with fractionated cyclophosphamide, vincristine, liposomal daunorubicin and dexamethasone, obtaining an ORR of $41 \%$, with high rate of complete response (CR) (38\%), but an OS of only 10 months [43]. A further development of this treatment schema, which alternated this regimen with high-dose methotrexate and cytarabine every other cycle and incorporated rituximab and granulocyte-macrophagecolony stimulating factor (GM-CSF), was used to treat 30 patients resulting in an ORR of $41 \%$ and an OS of 8.5 months. The toxicity of this treatment was high with $18 \%$ of patients dying during the first cycle of therapy [44].

The combination of cisplatin, fludarabine, cyclophosphamide, and cytarabine was also evaluated in 15 patients with RS showing dismal results (5\% ORR, 20\% treatment-related mortality in the first month) [45]. The rationale for developing this regimen is based on preclinical data demonstrating synergistic cytotoxic activity of cisplatin and the nucleoside analogue fludarabine $[46,47]$, and showing that the administration of fludarabine before 
cytarabine increases the cellular concentration of the active metabolite, cytarabine triphosphate [48].

Another platinum-based regimen for patients with RS based on the above described pharmacological rationale was developed at our center combining oxaliplatin, fludarabine, cytarabine and rituximab (OFAR). The activity of this treatment combination was explored in two trials: a total of 55 patients were treated with different dosing schedules obtaining ORR of $43-50 \%$ and a median survival of $6-8$ months. The most significant toxicities of this regimen were hematologic and infectious, with $>80 \%$ rate of grade $3-4$ neutropenia and $12-15 \%$ rate of grade 3-4 neutropenic fever $[49,50]$. Similar results were shown in a retrospective analysis evaluating the efficacy of platinum and cytarabine-based regimens in 28 patients with RS, performed by Durot and colleagues, which showed an ORR of $43 \%$ with $25 \%$ CR, and a median OS of 8.3 months [51].

Based on its efficacy in treating patients with other B cell lymphomas, ${ }^{90} \mathrm{Y}$ ibritumomab tiuxetan was also tested in 7 patients with RS, showing no responses and a median PFS of only 41 days [52].

Regarding the rare HVRS form, a retrospective systematic review of patients with CLL who developed HVRS between 1975 and 2011 identified 86 cases and confirmed that the combination of doxorubicin, bleomycin, vinblastine, and dacarbazine (ABVD) is the most commonly offered treatment strategy [12].

In the last few years, the therapeutic landscape for CLL and other B cell lymphomas has dramatically changed, with the introduction of small molecule inhibitors. Among these agents, ibrutinib has shown a remarkable efficacy in patients with CLL [53]. Ibrutinib has also demonstrated single-agent activity in patients with relapsed/refractory de novo DLBCL, and interestingly, the produced ORR was higher in patients with the more aggressive $A B C$ DLBCL compared to GCB DLBCL ( $n=80,37 \%$ vs $5 \%, p=0.0106$ ) [54]. In de novo DLBCL, the combination of ibrutinib with R-CHOP has also been explored and all 
18 patients who received the recommended phase II dose of ibrutinib $(560 \mathrm{mg} / \mathrm{die})$ obtained a response [55]. Based on these findings, the use of ibrutinib (with or without rituximab) in patients with RS has been proposed and anecdotic data were published [5658]. In most cases patients were heavily pretreated and some responses were observed, but results are inconsistent and further studies to explore the efficacy of BTK inhibitors in clinical trials, also in combination with other drugs, are needed. Moreover, the efficacy of other novel drugs such as BCL-2 antagonists, PI3K inhibitors and NOTCH1 inhibitors in patients with RS is being evaluated in recently designed studies.

Stem cell transplant (SCT) plays a role in the treatment of patients with RS. Only a minority of patients $(<15 \%)$ can undergo the procedure due to disease refractoriness and poor performance status. In the clinical database at The Univeristy of Texas MD Anderson Cancer Center, 148 patients with proven RS were identified between 1975 and 2005. Fourteen\% of these patients underwent SCT (17 alloSCT and 3 autoSCT), and they had a better long-term outcome compared to patients who did not. Moreover, the estimated cumulative 3-year survival probability for patients who received the SCT while in CR or PR was $75 \%$, compared with $21 \%$ for patients who did not achieve a response prior to SCT [9]. Patients with RS seen at Mayo Clinic between 1995 and 2013 were also studied $(n=120)$. Only $11 \%$ received a SCT ( $8 \%$ autoSCT, $2 \%$ alloSCT and $1 \%$ autoSCT followed by alloSCT) and the median OS of these patients was superior compared to those who did not undergo SCT (5.2 years vs 0.7 years, $p=0.005$ ) [59]. In a multicenter restrospective analysis, 59 patients with RS were analyzed: 34 patients received autoSCT and 25 received alloSCT, with $36 \%$ being refractory to chemotherapy at SCT. Reduced-intensity conditioning (RIC) was used in $72 \%$ of cases, and was found to be associated with longer relapse-free survival (RFS) after alloSCT in multivariate analysis. Three-year estimates of the probabilities of OS and RFS were $36 \%$ and $27 \%$ for alloSCT, and $59 \%$ and $45 \%$ for autoSCT [60]. In this latter study, also the disease status at the time of SCT was 
associated with survival, highlighting the potential utility of this procedure in a selected group of patients with a good performance status and a disease that is sensitive to chemotherapy.

\section{Conclusions}

$\mathrm{RS}$ remains a rare clinical occurrence. The low incidence explains the paucity of definitive data on the pathogenesis and prognosis of this disease, and also the difficulty in conducting clinical trials to explore new treatments.

The increasing understanding of the molecular mechanisms underlying RS transformation and of the relevant risk factors may help the clinicians to identify high-risk patients with CLL, who might need to be followed more strictly as compared to patients with indolent disease.

RS is still an unmet clinical need and current data on treatment approaches mainly derives from small non-randomized trials. The available therapeutic strategies are not satisfactory: besides the low efficacy, they carry a high mortality and adverse event rate, possibly due also to the fact that patients are frequently heavily pretreated and with a poor performance status. The availability of new drugs with novel mechanisms of action (i.e. BCR inhibitors and BCL-2 antagonists), which are characterized by a better tolerability compared to standard intensive chemotherapy, offers promising new tools for this aggressive disease. Moreover, the growing understanding of the molecular basis of RS will hopefully help to identify novel therapeutic targets. 


\section{References}

1. Richter MN (1928) Generalized Reticular Cell Sarcoma of Lymph Nodes Associated with Lymphatic Leukemia. The American journal of pathology 4 (4):285-292.287

2. Lortholary P, Boiron M, Ripault P, Levy JP, Manus A, Bernard J (1964) Chronic lymphoid leukemia secondarily associated with a malignant reticulopathy: Richter's syndrome. Nouvelle revue francaise d'hematologie 4:621-644

3. Swerdlow SH, Campo, E., Harris, N.L., Jaffe, E.S., Pileri, S.A., Stein, H., Thiele, J., Vardiman, J.W (2008) WHO Classification of Tumours of Haematopoietic and Lymphoid Tissues, Fourth Edition. In:

4. Choi WW, Weisenburger DD, Greiner TC, Piris MA, Banham AH, Delabie J, Braziel RM, Geng H, Iqbal J, Lenz G, Vose JM, Hans CP, Fu K, Smith LM, Li M, Liu Z, Gascoyne RD, Rosenwald A, Ott G, Rimsza LM, Campo E, Jaffe ES, Jaye DL, Staudt LM, Chan WC (2009) A new immunostain algorithm classifies diffuse large B-cell lymphoma into molecular subtypes with high accuracy. Clinical cancer research : an official journal of the American Association for Cancer Research 15 (17):5494-5502. doi:10.1158/10780432.ccr-09-0113

5. Rossi D, Spina V, Deambrogi C, Rasi S, Laurenti L, Stamatopoulos K, Arcaini L, Lucioni M, Rocque GB, Xu-Monette ZY, Visco C, Chang J, Chigrinova E, Forconi F, Marasca R, Besson C, Papadaki T, Paulli M, Larocca LM, Pileri SA, Gattei V, Bertoni F, Foa R, Young KH, Gaidano G (2011) The genetics of Richter syndrome reveals disease heterogeneity and predicts survival after transformation. Blood 117 (12):3391-3401. doi:10.1182/blood2010-09-302174

6. Mao Z, Quintanilla-Martinez L, Raffeld M, Richter M, Krugmann J, Burek C, Hartmann E, Rudiger T, Jaffe ES, Muller-Hermelink HK, Ott G, Fend F, Rosenwald A (2007) lgVH mutational status and clonality analysis of Richter's transformation: diffuse large B-cell lymphoma and Hodgkin lymphoma in association with B-cell chronic lymphocytic leukemia (B-CLL) represent 2 different pathways of disease evolution. The American journal of surgical pathology 31 (10):1605-1614. doi:10.1097/PAS.0b013e31804bdaf8

7. Tsimberidou AM, O'Brien S, Kantarjian HM, Koller C, Hagemeister FB, Fayad L, Lerner S, Bueso-Ramos CE, Keating MJ (2006) Hodgkin transformation of chronic lymphocytic leukemia: the M. D. Anderson Cancer Center experience. Cancer 107 (6):1294-1302. doi:10.1002/cncr.22121

8. Mauro FR, Foa R, Giannarelli D, Cordone I, Crescenzi S, Pescarmona E, Sala R, Cerretti R, Mandelli F (1999) Clinical characteristics and outcome of young chronic lymphocytic leukemia patients: a single institution study of 204 cases. Blood 94 (2):448454

9. Tsimberidou AM, O'Brien S, Khouri I, Giles FJ, Kantarjian HM, Champlin R, Wen S, Do KA, Smith SC, Lerner S, Freireich EJ, Keating MJ (2006) Clinical outcomes and prognostic 
factors in patients with Richter's syndrome treated with chemotherapy or chemoimmunotherapy with or without stem-cell transplantation. Journal of clinical oncology : official journal of the American Society of Clinical Oncology 24 (15):2343-2351. doi:10.1200/jco.2005.05.0187

10. Rossi D, Spina V, Cerri M, Rasi S, Deambrogi C, De Paoli L, Laurenti L, Maffei R, Forconi F, Bertoni F, Zucca E, Agostinelli C, Cabras A, Lucioni M, Martini M, Magni M, Deaglio S, Ladetto M, Nomdedeu JF, Besson C, Ramponi A, Canzonieri V, Paulli M, Marasca R, Larocca LM, Carbone A, Pileri SA, Gattei V, Gaidano G (2009) Stereotyped Bcell receptor is an independent risk factor of chronic lymphocytic leukemia transformation to Richter syndrome. Clinical cancer research : an official journal of the American Association for Cancer Research 15 (13):4415-4422. doi:10.1158/1078-0432.ccr-08-3266

11. Parikh SA, Rabe KG, Call TG, Zent CS, Habermann TM, Ding W, Leis JF, Schwager SM, Hanson CA, Macon WR, Kay NE, Slager SL, Shanafelt TD (2013) Diffuse large B-cell lymphoma (Richter syndrome) in patients with chronic lymphocytic leukaemia (CLL): a cohort study of newly diagnosed patients. British journal of haematology 162 (6):774-782. doi:10.1111/bjh.12458

12. Bockorny B, Codreanu I, Dasanu CA (2012) Hodgkin lymphoma as Richter transformation in chronic lymphocytic leukaemia: a retrospective analysis of world literature. British journal of haematology 156 (1):50-66. doi:10.1111/j.1365-

2141.2011.08907.x

13. Rossi D, Cerri M, Capello D, Deambrogi C, Rossi FM, Zucchetto A, De Paoli L, Cresta S, Rasi S, Spina V, Franceschetti S, Lunghi M, Vendramin C, Bomben R, Ramponi A, Monga G, Conconi A, Magnani C, Gattei V, Gaidano G (2008) Biological and clinical risk factors of chronic lymphocytic leukaemia transformation to Richter syndrome. British journal of haematology 142 (2):202-215. doi:10.1111/j.1365-2141.2008.07166.x

14. Fabbri G, Khiabanian H, Holmes AB, Wang J, Messina M, Mullighan CG, Pasqualucci L, Rabadan R, Dalla-Favera R (2013) Genetic lesions associated with chronic lymphocytic leukemia transformation to Richter syndrome. The Journal of experimental medicine 210 (11):2273-2288. doi:10.1084/jem.20131448

15. Chigrinova E, Rinaldi A, Kwee I, Rossi D, Rancoita PM, Strefford JC, Oscier D, Stamatopoulos K, Papadaki T, Berger F, Young KH, Murray F, Rosenquist R, Greiner TC, Chan WC, Orlandi EM, Lucioni M, Marasca R, Inghirami G, Ladetto M, Forconi F, Cogliatti S, Votavova $H$, Swerdlow SH, Stilgenbauer S, Piris MA, Matolcsy A, Spagnolo D, Nikitin E, Zamo A, Gattei V, Bhagat G, Ott G, Zucca E, Gaidano G, Bertoni F (2013) Two main genetic pathways lead to the transformation of chronic lymphocytic leukemia to Richter syndrome. Blood 122 (15):2673-2682. doi:10.1182/blood-2013-03-489518

16. Rinaldi A, Mensah AA, Kwee I, Forconi F, Orlandi EM, Lucioni M, Gattei V, Marasca R, Berger F, Cogliatti S, Cavalli F, Zucca E, Gaidano G, Rossi D, Bertoni F (2013) Promoter methylation patterns in Richter syndrome affect stem-cell maintenance and cell cycle regulation and differ from de novo diffuse large B-cell lymphoma. British journal of haematology 163 (2):194-204. doi:10.1111/bjh.12515 
17. Rossi D, Khiabanian H, Spina V, Ciardullo C, Bruscaggin A, Fama R, Rasi S, Monti S, Deambrogi C, De Paoli L, Wang J, Gattei V, Guarini A, Foa R, Rabadan R, Gaidano G (2014) Clinical impact of small TP53 mutated subclones in chronic lymphocytic leukemia. Blood 123 (14):2139-2147. doi:10.1182/blood-2013-11-539726

18. Dolcetti R, Carbone A (2010) Epstein-Barr virus infection and chronic lymphocytic leukemia: a possible progression factor? Infectious agents and cancer 5:22.

doi:10.1186/1750-9378-5-22

19. Solh M, Rai KR, Peterson BL, Kolitz JE, Appelbaum FR, Tallman MS, Belch A, Larson RA, Morrison VA (2013) The impact of initial fludarabine therapy on transformation to Richter syndrome or prolymphocytic leukemia in patients with chronic lymphocytic leukemia: analysis of an intergroup trial (CALGB 9011). Leuk Lymphoma 54 (2):252-254. doi:10.3109/10428194.2012.710327

20. Catovsky D, Richards S, Matutes E, Oscier D, Dyer MJ, Bezares RF, Pettitt AR, Hamblin T, Milligan DW, Child JA, Hamilton MS, Dearden CE, Smith AG, Bosanquet AG, Davis Z, Brito-Babapulle V, Else M, Wade R, Hillmen P (2007) Assessment of fludarabine plus cyclophosphamide for patients with chronic lymphocytic leukaemia (the LRF CLL4 Trial): a randomised controlled trial. Lancet 370 (9583):230-239. doi:10.1016/s01406736(07)61125-8

21. Jain P, Keating M, Wierda W, Estrov Z, Ferrajoli A, Jain N, George B, James D, Kantarjian H, Burger J, O'Brien S (2015) Outcomes of patients with chronic lymphocytic leukemia after discontinuing ibrutinib. Blood 125 (13):2062-2067. doi:10.1182/blood-201409-603670

22. Maddocks KJ, Ruppert AS, Lozanski G, Heerema NA, Zhao W, Abruzzo L, Lozanski A, Davis M, Gordon A, Smith LL, Mantel R, Jones JA, Flynn JM, Jaglowski SM, Andritsos LA, Awan F, Blum KA, Grever MR, Johnson AJ, Byrd JC, Woyach JA (2015) Etiology of Ibrutinib Therapy Discontinuation and Outcomes in Patients With Chronic Lymphocytic Leukemia. JAMA oncology 1 (1):80-87. doi:10.1001/jamaoncol.2014.218

23. Rossi D, Spina V, Bomben R, Rasi S, Dal-Bo M, Bruscaggin A, Rossi FM, Monti S, Degan M, Ciardullo C, Serra R, Zucchetto A, Nomdedeu J, Bulian P, Grossi A, Zaja F, Pozzato G, Laurenti L, Efremov DG, Di-Raimondo F, Marasca R, Forconi F, Del Poeta G, Gaidano G, Gattei V (2013) Association between molecular lesions and specific B-cell receptor subsets in chronic lymphocytic leukemia. Blood 121 (24):4902-4905. doi:10.1182/blood-2013-02-486209

24. Villamor N, Conde L, Martinez-Trillos A, Cazorla M, Navarro A, Bea S, Lopez C, Colomer D, Pinyol M, Aymerich M, Rozman M, Abrisqueta P, Baumann T, Delgado J, Gine E, Gonzalez-Diaz M, Hernandez JM, Colado E, Payer AR, Rayon C, Navarro B, Jose Terol M, Bosch F, Quesada V, Puente XS, Lopez-Otin C, Jares P, Pereira A, Campo E, Lopez-Guillermo A (2013) NOTCH1 mutations identify a genetic subgroup of chronic lymphocytic leukemia patients with high risk of transformation and poor outcome.

Leukemia 27 (5):1100-1106. doi:10.1038/leu.2012.357 
25. Rossi D, Rasi S, Spina V, Fangazio M, Monti S, Greco M, Ciardullo C, Fama R, Cresta S, Bruscaggin A, Laurenti L, Martini M, Musto P, Forconi F, Marasca R, Larocca LM, Foa R, Gaidano G (2012) Different impact of NOTCH1 and SF3B1 mutations on the risk of chronic lymphocytic leukemia transformation to Richter syndrome. British journal of haematology 158 (3):426-429. doi:10.1111/j.1365-2141.2012.09155.x

26. Rossi D, Lobetti Bodoni C, Genuardi E, Monitillo L, Drandi D, Cerri M, Deambrogi C, Ricca I, Rocci A, Ferrero S, Bernocco E, Capello D, De Paoli L, Bergui L, Boi M, Omede P, Massaia M, Tarella C, Passera R, Boccadoro M, Gaidano G, Ladetto M (2009) Telomere length is an independent predictor of survival, treatment requirement and Richter's syndrome transformation in chronic lymphocytic leukemia. Leukemia 23 (6):1062-1072. doi:10.1038/leu.2008.399

27. Aydin S, Rossi D, Bergui L, D'Arena G, Ferrero E, Bonello L, Omede P, Novero D, Morabito F, Carbone A, Gaidano G, Malavasi F, Deaglio S (2008) CD38 gene polymorphism and chronic lymphocytic leukemia: a role in transformation to Richter syndrome? Blood 111 (12):5646-5653. doi:10.1182/blood-2008-01-129726

28. Rasi S, Spina V, Bruscaggin A, Vaisitti T, Tripodo C, Forconi F, De Paoli L, Fangazio M, Sozzi E, Cencini E, Laurenti L, Marasca R, Visco C, Xu-Monette ZY, Gattei V, Young KH, Malavasi F, Deaglio S, Gaidano G, Rossi D (2011) A variant of the LRP4 gene affects the risk of chronic lymphocytic leukaemia transformation to Richter syndrome. British journal of haematology 152 (3):284-294. doi:10.1111/j.1365-2141.2010.08482.x

29. Bruzzi JF, Macapinlac H, Tsimberidou AM, Truong MT, Keating MJ, Marom EM, Munden RF (2006) Detection of Richter's transformation of chronic lymphocytic leukemia by PET/CT. Journal of nuclear medicine : official publication, Society of Nuclear Medicine 47 (8):1267-1273

30. Falchi L, Keating MJ, Marom EM, Truong MT, Schlette EJ, Sargent RL, Trinh L, Wang X, Smith SC, Jain N, Estrov Z, O'Brien S, Wierda WG, Lerner S, Ferrajoli A (2014) Correlation between FDG/PET, histology, characteristics, and survival in 332 patients with chronic lymphoid leukemia. Blood 123 (18):2783-2790. doi:10.1182/blood-2013-11-536169

31. Mauro FR, Chauvie S, Paoloni F, Biggi A, Cimino G, Rago A, Gentile M, Morabito F, Coscia M, Bello M, Sacchetti GM, Rossi D, Laurenti L, Autore F, Campanelli M, Trastulli F, Nicolai E, Riminucci M, Gaidano G, Guarini A, Gallamini A, Foa R (2015) Diagnostic and prognostic role of $\mathrm{PET} / \mathrm{CT}$ in patients with chronic lymphocytic leukemia and progressive disease. Leukemia 29 (6):1360-1365. doi:10.1038/leu.2015.21

32. Michallet AS, Sesques P, Rabe KG, Itti E, Tordot J, Tychyj-Pinel C, Baseggio L, Subtil F, Salles G, Dupuis JM, Conte MJ (2015) An 18F-FDG-PET maximum standardized uptake value $>10$ represents a novel valid marker for discerning Richter's Syndrome. Leuk Lymphoma:1-10. doi:10.3109/10428194.2015.1099643

33. Gine E, Martinez A, Villamor N, Lopez-Guillermo A, Camos M, Martinez D, Esteve J, Calvo X, Muntanola A, Abrisqueta P, Rozman M, Rozman C, Bosch F, Campo E, Montserrat E (2010) Expanded and highly active proliferation centers identify a histological 
subtype of chronic lymphocytic leukemia ("accelerated" chronic lymphocytic leukemia) with aggressive clinical behavior. Haematologica 95 (9):1526-1533.

doi:10.3324/haematol.2010.022277

34. Hallek M, Cheson BD, Catovsky D, Caligaris-Cappio F, Dighiero G, Dohner H, Hillmen P, Keating MJ, Montserrat E, Rai KR, Kipps TJ (2008) Guidelines for the diagnosis and treatment of chronic lymphocytic leukemia: a report from the International Workshop on Chronic Lymphocytic Leukemia updating the National Cancer Institute-Working Group 1996 guidelines. Blood 111 (12):5446-5456. doi:10.1182/blood-2007-06-093906

35. Kuppers R, Duhrsen U, Hansmann ML (2014) Pathogenesis, diagnosis, and treatment of composite lymphomas. The Lancet Oncology 15 (10):e435-446. doi:10.1016/s14702045(14)70153-6

36. Omoti CE, Omoti AE (2008) Richter syndrome: a review of clinical, ocular, neurological and other manifestations. British journal of haematology 142 (5):709-716.

doi:10.1111/j.1365-2141.2008.07248.x

37. Conte MJ, Bowen DA, Wiseman GA, Rabe KG, Slager SL, Schwager SM, Call TG, Viswanatha DS, Zent CS (2014) Use of positron emission tomography-computed tomography in the management of patients with chronic lymphocytic leukemia/small lymphocytic lymphoma. Leuk Lymphoma 55 (9):2079-2084.

doi:10.3109/10428194.2013.869801

38. Robertson LE, Pugh W, O'Brien S, Kantarjian H, Hirsch-Ginsberg C, Cork A, McLaughlin P, Cabanillas F, Keating MJ (1993) Richter's syndrome: a report on 39 patients. Journal of clinical oncology : official journal of the American Society of Clinical Oncology 11 (10):1985-1989

39. Harousseau JL, Flandrin G, Tricot G, Brouet JC, Seligmann M, Bernard J (1981) Malignant lymphoma supervening in chronic lymphocytic leukemia and related disorders. Richter's syndrome: a study of 25 cases. Cancer 48 (6):1302-1308

40. Langerbeins $P$, Busch R, Anheier N, Durig J, Bergmann M, Goebeler ME, Hurtz HJ, Stauch MB, Stilgenbauer S, Dohner H, Fink AM, Cramer P, Fischer K, Wendtner CM, Hallek M, Eichhorst B (2014) Poor efficacy and tolerability of R-CHOP in relapsed/refractory chronic lymphocytic leukemia and Richter transformation. American journal of hematology 89 (12):E239-243. doi:10.1002/ajh.23841

41. Tadmor T, Shvidel L, Bairey O, Goldschmidt N, Ruchlemer R, Fineman R, RahimiLevene N, Herishanu Y, Yuklea M, Arad A, Aviv A, Polliack A (2014) Richter's transformation to diffuse large B-cell lymphoma: a retrospective study reporting clinical data, outcome, and the benefit of adding rituximab to chemotherapy, from the Israeli CLL Study Group. American journal of hematology 89 (11):E218-222. doi:10.1002/ajh.23826

42. Eyre TA, Clifford R, Roberts C, Boyle L, Francis A, Schuh A, Dutton SJ (2015) Single arm NCRI phase II study of CHOP in combination with Ofatumumab in induction and 
maintenance for patients with newly diagnosed Richter's syndrome. BMC cancer 15:52. doi:10.1186/s12885-015-1048-9

43. Dabaja BS, O'Brien SM, Kantarjian HM, Cortes JE, Thomas DA, Albitar M, Schlette ES, Faderl S, Sarris A, Keating MJ, Giles FJ (2001) Fractionated cyclophosphamide, vincristine, liposomal daunorubicin (daunoXome), and dexamethasone (hyperCVXD) regimen in Richter's syndrome. Leuk Lymphoma 42 (3):329-337.

doi:10.3109/10428190109064589

44. Tsimberidou AM, Kantarjian HM, Cortes J, Thomas DA, Faderl S, Garcia-Manero G, Verstovsek S, Ferrajoli A, Wierda W, Alvarado Y, O'Brien SM, Albitar M, Keating MJ, Giles FJ (2003) Fractionated cyclophosphamide, vincristine, liposomal daunorubicin, and dexamethasone plus rituximab and granulocyte-macrophage-colony stimulating factor (GM-CSF) alternating with methotrexate and cytarabine plus rituximab and GM-CSF in patients with Richter syndrome or fludarabine-refractory chronic lymphocytic leukemia. Cancer 97 (7):1711-1720. doi:10.1002/cncr.11238

45. Tsimberidou AM, O'Brien SM, Cortes JE, Faderl S, Andreeff M, Kantarjian HM, Keating MJ, Giles FJ (2002) Phase II study of fludarabine, cytarabine (Ara-C), cyclophosphamide, cisplatin and GM-CSF (FACPGM) in patients with Richter's syndrome or refractory lymphoproliferative disorders. Leuk Lymphoma 43 (4):767-772. doi:10.1080/10428190290016872

46. Yang LY, Li L, Keating MJ, Plunkett W (1995) Arabinosyl-2-fluoroadenine augments cisplatin cytotoxicity and inhibits cisplatin-DNA cross-link repair. Molecular pharmacology 47 (5):1072-1079

47. Li L, Liu X, Glassman AB, Keating MJ, Stros M, Plunkett W, Yang LY (1997) Fludarabine triphosphate inhibits nucleotide excision repair of cisplatin-induced DNA adducts in vitro. Cancer research 57 (8):1487-1494

48. Gandhi V, Kemena A, Keating MJ, Plunkett W (1992) Fludarabine infusion potentiates arabinosylcytosine metabolism in lymphocytes of patients with chronic lymphocytic leukemia. Cancer research 52 (4):897-903

49. Tsimberidou AM, Wierda WG, Plunkett W, Kurzrock R, O'Brien S, Wen S, Ferrajoli A, Ravandi-Kashani F, Garcia-Manero G, Estrov Z, Kipps TJ, Brown JR, Fiorentino A, Lerner S, Kantarjian HM, Keating MJ (2008) Phase I-II study of oxaliplatin, fludarabine, cytarabine, and rituximab combination therapy in patients with Richter's syndrome or fludarabine-refractory chronic lymphocytic leukemia. Journal of clinical oncology : official journal of the American Society of Clinical Oncology 26 (2):196-203.

doi:10.1200/jco.2007.11.8513

50. Tsimberidou AM, Wierda WG, Wen S, Plunkett W, O'Brien S, Kipps TJ, Jones JA, Badoux X, Kantarjian H, Keating MJ (2013) Phase I-II clinical trial of oxaliplatin, fludarabine, cytarabine, and rituximab therapy in aggressive relapsed/refractory chronic lymphocytic leukemia or Richter syndrome. Clinical lymphoma, myeloma \& leukemia 13 (5):568-574. doi:10.1016/j.clml.2013.03.012 
51. Durot E, Michallet AS, Lepretre S, Le QH, Leblond V, Delmer A (2015) Platinum and high-dose cytarabine-based regimens are efficient in ultra high/high-risk chronic lymphocytic leukemia and Richter's syndrome: results of a French retrospective multicenter study. European journal of haematology 95 (2):160-167. doi:10.1111/ejh.12474

52. Tsimberidou AM, Murray JL, O'Brien S, Wierda WG, Keating MJ (2004) Yttrium-90 ibritumomab tiuxetan radioimmunotherapy in Richter syndrome. Cancer 100 (10):21952200. doi:10.1002/cncr.20252

53. Byrd JC, Furman RR, Coutre SE, Burger JA, Blum KA, Coleman M, Wierda WG, Jones JA, Zhao W, Heerema NA, Johnson AJ, Shaw Y, Bilotti E, Zhou C, James DF, O'Brien S (2015) Three-year follow-up of treatment-naive and previously treated patients with CLL and SLL receiving single-agent ibrutinib. Blood 125 (16):2497-2506. doi:10.1182/blood-2014-10-606038

54. Wilson WH, Young RM, Schmitz R, Yang Y, Pittaluga S, Wright G, Lih CJ, Williams PM, Shaffer AL, Gerecitano J, de Vos S, Goy A, Kenkre VP, Barr PM, Blum KA, Shustov A, Advani R, Fowler NH, Vose JM, Elstrom RL, Habermann TM, Barrientos JC (2015) Targeting B cell receptor signaling with ibrutinib in diffuse large B cell lymphoma. 21 (8):922-926. doi:10.1038/nm.3884

55. Younes A, Thieblemont C, Morschhauser F, Flinn I, Friedberg JW, Amorim S, Hivert B, Westin J, Vermeulen J, Bandyopadhyay N, de Vries R, Balasubramanian S, Hellemans P, Smit JW, Fourneau N, Oki Y (2014) Combination of ibrutinib with rituximab, cyclophosphamide, doxorubicin, vincristine, and prednisone (R-CHOP) for treatment-naive patients with CD20-positive B-cell non-Hodgkin lymphoma: a non-randomised, phase $1 \mathrm{~b}$ study. The Lancet Oncology 15 (9):1019-1026. doi:10.1016/s1470-2045(14)70311-0

56. Giri S, Hahn A, Yaghmour G, Martin MG (2015) Ibrutinib has some activity in Richter's syndrome. Blood cancer journal 5:e277. doi:10.1038/bcj.2014.98

57. Lamar Z, Kennedy L, Kennedy B, Lynch M, Goad A, Hurd D, Mclver Z (2015) Ibrutinib and rituximab induced rapid response in refractory Richter syndrome. Clinical case reports 3 (7):615-617. doi:10.1002/ccr3.269

58. Tsang M, Shanafelt TD, Call TG, Ding W, Chanan-Khan A, Leis JF, Nowakowski GS, Bowen D, Conte M, Schwager SM, Slager SL, Kay NE, Hanson CA, Parikh SA (2015) The efficacy of ibrutinib in the treatment of Richter syndrome. Blood 125 (10):1676-1678. doi:10.1182/blood-2014-12-610782

59. Sharma RG, Call TG, Habermann TM, Ding W, Leis JF, Schwager S, Hanson CA, Macon WR, Tschumper RC, Jelinek DF, Kay NE, Slager SL, Rabe KG, Shanafelt TD (2013) Outcomes Of Chronic Lymphocytic Leukemia Patients With Richter Syndrome. Blood 122 (21):4179-4179

60. Cwynarski K, van Biezen A, de Wreede L, Stilgenbauer S, Bunjes D, Metzner B, Koza V, Mohty M, Remes K, Russell N, Nagler A, Scholten M, de Witte T, Sureda A, Dreger P (2012) Autologous and allogeneic stem-cell transplantation for transformed chronic 
lymphocytic leukemia (Richter's syndrome): A retrospective analysis from the chronic lymphocytic leukemia subcommittee of the chronic leukemia working party and lymphoma working party of the European Group for Blood and Marrow Transplantation. Journal of clinical oncology : official journal of the American Society of Clinical Oncology 30 (18):2211-2217. doi:10.1200/jco.2011.37.4108 
Table 1. Summary of key clinical trials for the treatment of RS

\begin{tabular}{|c|c|c|c|c|c|}
\hline Trial & Regimen & & Response & Survival & Toxicity \\
\hline $\begin{array}{l}\text { Langerbeins et al.[40] } \\
\text { Am J Hematol, 2014 } \\
\text { Phase II } \\
n=15\end{array}$ & $\begin{array}{l}\text { R-CHOP } \\
\text { (up to } 8 \text { cycles) }\end{array}$ & $\begin{array}{l}\text { - cyclophosphamide } 750 \mathrm{mg} / \mathrm{m}^{2} \mathrm{D} 1 \\
\text { - adriamycin } 50 \mathrm{mg} / \mathrm{m}^{2} \mathrm{D} 1 \\
\text { - vincristine } 1,4 \mathrm{mg} / \mathrm{m}^{2} \mathrm{D} 1 \\
\text { - prednisone } 100 \mathrm{mg} \text { D1-D5 } \\
\text { - rituximab } 375 \mathrm{mg} / \mathrm{m} 2 \mathrm{D} 1\end{array}$ & $\begin{array}{l}\text { ORR 67\% } \\
\text { CR 7\% } \\
\text { PR } 60 \%\end{array}$ & $\begin{array}{l}\text { PFS: } 10 \text { months } \\
\text { OS: } 21 \text { months }\end{array}$ & $\begin{array}{l}\text { G3-4 anemia } 75 \% \\
\text { G3-4 neutropenia } 55 \% \\
\text { G3-4 thrombocytopenia } 65 \% \\
\text { All grade infections } 67 \% \\
\text { G3-4 infections } 28 \%\end{array}$ \\
\hline $\begin{array}{l}\text { Dabaja et al. [43] } \\
\text { Leuk Lymphoma, } 2001 \\
\text { Phase II } \\
\mathrm{n}=29\end{array}$ & $\begin{array}{l}\text { hyperCVXD } \\
\text { (up to } 6 \text { cycles) }\end{array}$ & $\begin{array}{l}\text { - cyclophosphamide } 300 \mathrm{mg} / \mathrm{m} 2 \text { twice daily D1-D3 } \\
\text { - vincristine } 2 \mathrm{mg} \mathrm{D} 4 \text { and D11 } \\
\text { - daunoXome } 40 \mathrm{mg} / \mathrm{m} 2 \mathrm{D} 3-\mathrm{D} 5 \\
\text { - dexamethasone } 40 \mathrm{mg} \text { D1-4 and D11 } \\
\text { (+ G-CSF) }\end{array}$ & $\begin{array}{l}\text { ORR 41\% } \\
\text { CR 38\% }\end{array}$ & OS: 10 months & $\begin{array}{l}\text { G3-4 neutropenia } 100 \% \\
\text { G3-4 infections } 39 \% \\
\text { G3-4 thrombocytopenia } 79 \% \text { of the first } \\
\text { cycles } \\
\text { Pneumonia } 15 \% \text { of cycles } \\
\text { Sepsis } 8 \% \text { of cycles } \\
\text { Mortality rate } 20 \%\end{array}$ \\
\hline $\begin{array}{l}\text { Tsimberidou et al. [44] } \\
\text { Cancer, } 2003 \\
\text { Phase II } \\
\mathrm{n}=30\end{array}$ & $\begin{array}{l}\text { R-hyper- } \\
\text { CVXD/R-MTX- } \\
\text { Ara-C } \\
\text { (alternating for } 6 \\
\text { cycles) }\end{array}$ & $\begin{array}{l}\text { CYCLES 1, 3, 5: } \\
\text { - rituximab } 375 \mathrm{mg} / \mathrm{m}^{2} \text { D1 } \\
\text { - cyclophosphamide } 300 \mathrm{mg} / \mathrm{m} 2 \text { twice daily D3-D5 in } \\
\text { cycle } 1, \mathrm{D} 1-3 \mathrm{cycle} 3 \text { and } 5 \\
\text { - vincristine } 2 \mathrm{mg} \text { D6 and D13 in cycle } 1 \text {, D4 and D11 } \\
\text { cycle } 3 \text { and } 5 \\
\text { - daunoXome } 40 \mathrm{mg} / \mathrm{m} 2 \text { D5-D7 in cycle 1, D3-5 cycle } 3 \\
\text { and } 5 \\
\text { - dexamethasone } 40 \mathrm{mg} \text { D3-D6 and D13-D16 in cycle 1, } \\
\text { D1-4 and D11-D14 cycle } 3 \text { and } 5 \\
\text { CYCLES 2, } 4,6: \\
\text { - rituximab } 375 \mathrm{mg} / \mathrm{m}^{2} \text { D1 } \\
\text { - methotrexate } 1 \mathrm{~g} / \mathrm{m} 2 \text { D1 } \\
\text { - cytarabine } 3 \mathrm{~g} / \mathrm{m} 2 \text { twice daily D2-D3 } \\
\text { (+GM-CSF) }\end{array}$ & $\begin{array}{l}\text { ORR } 41 \% \\
\text { CR } 19 \% \\
\text { PR } 22 \%\end{array}$ & OS: 8 months & $\begin{array}{l}\text { G4 neutropenia } 100 \% \\
\text { G4 thrombocytopenia } 40 \% \text { of cycles } \\
\text { G3-4 sepsis } 39 \% \text { of cycles } \\
\text { Deaths during first cycle } 18 \% \\
\text { Deaths during second cycle } 4 \%\end{array}$ \\
\hline $\begin{array}{l}\text { Tsimberidou et al. [49] } \\
\text { JCO, } 2008 \\
\text { Phase I/II } \\
n=20\end{array}$ & $\begin{array}{l}\text { OFAR-1 } \\
\text { (up to } 6 \text { cycles) }\end{array}$ & $\begin{array}{l}\text { - oxaliplatin (17.5, 20, or } 25 \mathrm{mg} / \mathrm{m} 2 \text { in phase } 1,25 \mathrm{mg} / \mathrm{m} 2 \\
\text { in phase II) D1-D4 } \\
\text { - fludarabine } 30 \mathrm{mg} / \mathrm{m} 2 \text { D2-D3 } \\
\text { - cytarabine } 1 \mathrm{~g} / \mathrm{m} 2 \text { D2-D3 } \\
\text { - rituximab } 375 \mathrm{mg} / \mathrm{m} 2 \text { cycle } 1 \text { D3, cycles 2-6 D1 } \\
\text { (+ pegfilgrastim) }\end{array}$ & $\begin{array}{l}\text { ORR } 50 \% \\
\text { CR } 20 \%\end{array}$ & $\begin{array}{l}\text { 6-month PFS: } 54 \% \\
\text { 6-month OS: } 59 \%\end{array}$ & $\begin{array}{l}\text { G4 neutropenia } 84 \% \\
\text { G4 thrombocytopenia } 94 \% \\
\text { G4 anemia } 56 \%\end{array}$ \\
\hline $\begin{array}{l}\text { Tsimberidou et al. [50] } \\
\text { Clin Lymp, Myel \& Leuk, } 2013 \\
\text { Phase } 1 / / I \\
n=35\end{array}$ & $\begin{array}{l}\text { OFAR-2 } \\
\text { (up to } 6 \text { cycles) }\end{array}$ & $\begin{array}{l}\text { - oxaliplatin } 30 \mathrm{mg} / \mathrm{m} 2 \text { D1-D4 } \\
\text { - fludarabine } 30 \mathrm{mg} / \mathrm{m} 2 \text { D2-D3 or D2-D4 or D2-D5 } \\
\text { - cytarabine } 0.5 \mathrm{~g} / \mathrm{m} 2 \text { D2-D3 or D2-D4 or D2-D5 } \\
\text { - rituximab } 375 \mathrm{mg} / \mathrm{m} 2 \text { cycle } 1 \text { D3, cycles 2-6 D1 } \\
\text { (+ pegfilgrastim) }\end{array}$ & $\begin{array}{l}\text { ORR 43\% } \\
\text { CR } 9 \%\end{array}$ & $\begin{array}{l}\text { OS: } 6.6 \text { months } \\
\text { 2-year OS: } 19.7 \%\end{array}$ & $\begin{array}{l}\text { G4 neutropenia } 89 \% \\
\text { G4 thrombocytopenia } 77 \% \\
\text { G4 anemia } 50 \%\end{array}$ \\
\hline
\end{tabular}




\section{Figure 1. Decision points for diagnosis and management of RS}

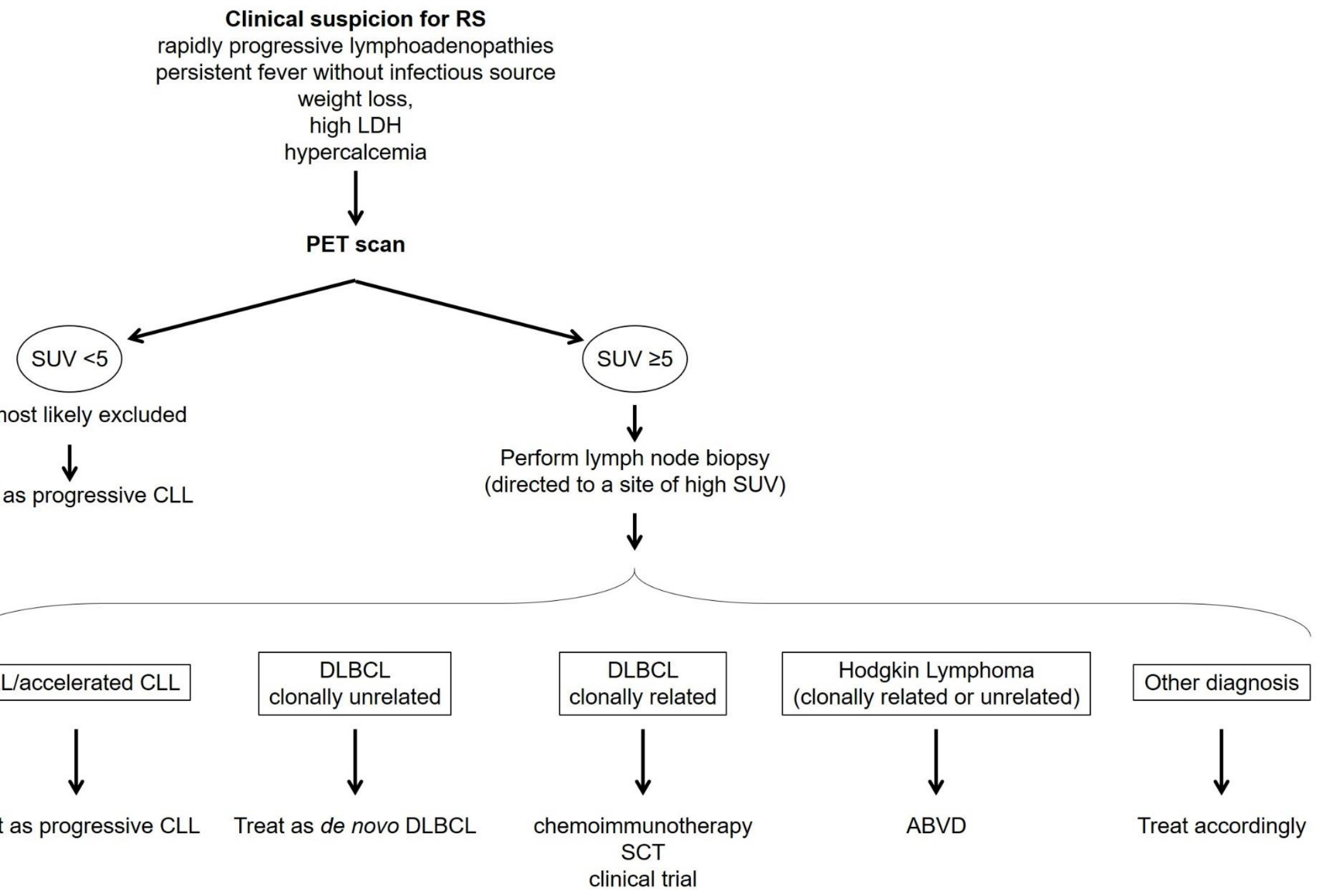

